\title{
PENGARUH PEMBELAJARAN ELEKTRONIK (E-LEARNING) TERHADAP MUTU BELAJAR MAHASISWA
}

\author{
Euis Karwati \\ Universitas Islam Nusantara (UNINUS), Jl Sukarno Hatta No. 530 Bandung- (40286), \\ Telp. 022-750-9656, fax. 022-750-9656. Hp.0811215702.E-mail: andilalayau@gmail.com \\ Naskah diterima 28 Januari 2014, direvisi tanggal 30 Mei 2014,disetujui tanggal 23 Juni 2014
}

\section{THE INFLUENCE OF E-LEARNING BASED ON INFORMATION TECHNOLOGY TOWARD STUDENTS QUALITY OF LEARNING}

\begin{abstract}
Abstact
Universitas Islam Nusantara (UNINUS) currently manages the Faculty Teacher Training and Education Science (FKIP), with increasing number of students each year. However, the increase in students has not been fully supported by an increase the quality of learning. This study aims to know about e-learning and quality of learning, and also to analyze was there any influence from e-learning to quality of learning at FKIP UNINUS at Bandung City. The method used is descriptive and verification. The sample was 100 college students of FKIP UNINUS at Bandung City. The sampling technique used simple random sampling (SRS). Analysis using linear regression analysis. Based on these results, it can be concluded that the e-learning is in the high category, while quality of learning is in the medium category. In addition, the obtained findings that e-learning has positive and significant impact on quality of learning at FKIP UNINUS Bandung. Thus, e-learning needs to be improved because it has proven to be able to increase the quality of learning at FKIP UNINUS Bandung.
\end{abstract}

Keywords: information and communication technology, e-learning, quality of learning

\begin{abstract}
Abstrak
Universitas Islam Nusantara (UNINUS) saat ini mengelola Fakultas Keguruan dan Ilmu Pendidikan (FKIP) di mana dalam perkembangannya jumlah mahasiswa FKIP UNINUS setiap tahun mengalami peningkatan. Namun demikian, kenaikan tersebut belum sepenuhnya didukung oleh peningkatan kualitas pembelajaran bagi mahasiswa. Penelitian ini bertujuan untuk menganalisis bagaimana pembelajaran elektronik di FKIP UNINUS; bagaimana kualitas pembelajaran di FKIP UNINUS; dan untuk mengetahui apakah pembelajaran elektronik berpengaruh terhadap kualitas pembelajaran mahasiswa di FKIP UNINUS. Metode yang digunakan dalam penelitian ini adalah metode deskriptif dan verifikatif. Sampel yang dijadikan unit analisis adalah 100 mahasiswa FKIP UNINUS. Teknik sampling yang digunakan simpel random sampling (SRS). Teknik analisis data menggunakan analisis regresi linier sederhana. Berdasarkan hasil penelitian ditemukan bahwa pembelajaran elektronik berada dalam kategori yang tinggi, sementara kualitas pembelajaran berada dalam kategori cukup. Selain itu, diperoleh temuan bahwa pembelajaran elektronik memiliki pengaruh yang positif dan signifikan terhadap kualitas pembelajaran di FKIP UNINUS. Dengan demikian, pembelajaran elektronik perlu ditingkatkan karena terbukti mampu meningkatkan kualitas pembelajaran di FKIP UNINUS.
\end{abstract}

Kata kunci: teknologi informasi dan komunikasi, pembelajaran elektronik, kualitas pembelajaran. 


\section{PENDAHULUAN}

Seiring dengan perkembangan Teknologi Informasi dan Komunikasi (TIK) yang semakin pesat, kebutuhan akan suatu konsep dan mekanisme belajar mengajar (pendidikan) berbasis TI menjadi tidak terelakkan lagi. Konsep yang kemudian terkenal dengan sebutan e-learning telah membawa pengaruh terjadinya proses transformasi pendidikan konvensional ke dalam bentuk digital, baik secara isi (contents) dan sistemnya. Saat ini konsep $e$ learning sudah banyak diterima oleh masyarakat dunia, terbukti dengan maraknya implementasi e-learning khususnya di lembaga pendidikan (sekolah, pelatihan/training dan universitas). Beberapa perguruan tinggi menyelenggarakan kegiatan pembelajaran elektronik sebagai suplemen (tambahan) terhadap materi pelajaran yang disajikan secara reguler di kelas. Namun, beberapa perguruan tinggi lainnya menyelenggarakan e-learning sebagai alternatif bagi mahasiswa yang karena satu dan lain hal berhalangan mengikuti perkuliahan secara tatap muka. Dalam kaitan ini, maka e-learning berfungsi sebagai opsi (pilihan) bagi mahasiswa.

Kecenderungan untuk mengembangkan e-learning sebagai salah satu alternatif pembelajaran di berbagai lembaga pendidikan semakin meningkat sejalan dengan perkembangan di bidang teknologi komunikasi dan informasi. Infrastruktur di bidang telekomunikasi yang menunjang penyelenggaraan e-learning tidak lagi hanya menjadi monopoli kota-kota besar, tetapi secara bertahap sudah mulai dapat dinikmati oleh mereka yang berada di kota-kota di tingkat kabupaten. Artinya, masyarakat yang berada di kabupaten telah dapat menggunakan fasilitas internet.

Universitas Islam Nusantara berada di Kota Bandung. UNINUS semula bernama Universitas Nahdlatul Ulama (UNNU) yang berdiri pada tanggal 30 November 1959. Dalam perkembangannya, pada tanggal 30 Agustus 1969, UNNU, Akademi Pendidikan Agama Islam, Universitas Ibnu Khaldun, dan Universitas Muhammadiyah, kemudian melebur menjadi Universitas Islam Nusantara (UNINUS). UNINUS saat ini mengelola FKIP yang terdiri dari Jurusan Ilmu Pendidikan, Jurusan Pendidikan Bahasa dan Seni, Jurusan Pendidikan Matematika dan IPA, Jurusan Pendidikan IPS, serta Jurusan Pendidikan Anak Usia Dini.

Perkembangan jumlah mahasiswa FKIP UNINUS Bandung setiap tahunnya mengalami peningkatan. Namun peningkatan tersebut belum sepenuhnya didukung oleh peningkatan mutu belajarnya. Berdasarkan hasil pengolahan data dan observasi, diketahui bahwa mutu belajar mahasiswa UNINUS Bandung mengalami kemandegan (Karwati, 2013). Hal tersebut disinyalir akibat kurang optimalnya pemanfaatan e-learning dalam proses belajar mengajar. Berdasarkan hal tersebut, maka penelitian ini dirumuskan dalam rumusan masalah sebagai berikut: Sejauhmana pembelajaran elektronik (elearning) di FKIP UNINUS Bandung; Sejauhmana mutu belajar mahasiswa FKIP UNINUS Bandung? Seberapa kuat pengaruh pembelajaran elektronik (e-learning) terhadap mutu belajar mahasiswa FKIP UNINUS Bandung? Tujuan penelitian ini adalah menganalisis pembelajaran elektronik (elearning) di FKIP UNINUS Bandung; menganalisis kualitas pembelajaran mahasiswa FKIP UNINUS Bandung; mengetahui apakah pembelajaran elektronik (e-learning) berpengaruh terhadap kualitas pembelajaran.

Penelitian ini memberikan manfaat teoretis dan manfaat praktis. Manfaat teoretisnya adalah hasil penelitian ini diharapkan akan memberikan sumbangan teoretis bagi pengembangan ilmu, terutama yang berkaitan dengan pembelajaran elektronik (e-learning) dan kualitas pembelajaran. Sedangkan manfaat praktisnya adalah memberikan informasi tambahan sebagai bahan untuk dijadikan dasar pertimbangan dalam rangka mengambil kebijakan atas pentingnya penerapan pembelajaran elektronik (e-learning) sebagai upaya dalam meningkatkan kualitas pembelajaran di lingkungan FKIP UNINUS. 


\section{LANDASAN KONSEP}

\section{Teknologi dan Informasi}

Sistem pembelajaran konvensional dianggap tidak sesuai lagi dengan perkembangan zaman, selain disebabkan adanya pergeseran pendidikan yang tadinya berfokus pada dosen menjadi berfokus pada mahasiswa dan lingkungan yang ada di sekitarnya. Banyak mahasiswa merasa bahwa sistem pembelajaran konvensional tidak menarik dan tidak mampu menumbuhkan minat mereka untuk terus belajar. Sehingga kehadiran teknologi dan informasi menjadi solusi penting untuk menumbuhkan minat belajar mahasiswa.

Terdapat beberapa alasan yang melandasi pentingnya penggunaan teknologi informasi (TI) dalam dunia pendidikan, yaitu: 1) Banyak sekolah yang memiliki komputer sendiri sehingga dimungkinkan untuk dikembangkan paket belajar PersonalInteraktif yang materi ajarnya dikemas dalam suatu software. Peserta dapat belajar dengan cara menjalankan program komputer atau perangkat lunak tersebut di komputer secara mandiri dan di lokasi masing-masing. Melalui paket program belajar ini peserta ajar dapat melakukan simulasi atau juga umpan balik tentang kemajuan belajarnya; 2) Negara Indonesia terdiri atas ribuan pulau yang tersebar dalam wilayah yang sangat luas, serta dihuni lebih dari 200 juta penduduk dengan distribusi secara tidak homogen. Kondisi ini memang disadari memiliki kendala ketika akan diterapkan sistem pendidikan konvensional (tatap muka). Maka teknologi informasi yang mungkin diterapkan untuk kondisi tersebut adalah melalui jaringan internet. Melalui pembelajaran ini proses belajar dapat dijalankan secara online atau didownload untuk keperluan offline. Mahasiswa dapat mengakses sistem kapan saja dan sesering mungkin (time independence), tidak terbatas pada jam belajar dan tidak tergantung pada tempat (place independence). Fungsi lain yang dapat digunakan untuk proses belajar tersebut melalui e-mail atau grup diskusi, yang dapat berinteraksi dan mengirimkan naskah secara elektronik. Pada perguruan tinggi, pemanfaatan teknologi informasi telah dibangun dalam suatu sistem yang disebut e-university atau electronic university. Pengembangan e-university ini bertujuan untuk mendukung penyelenggaraan pendidikan sehingga dapat menyediakan layanan informasi yang lebih baik kepada komunitasnya baik di dalam (internal) maupun diluar (eksternal) perguruan tinggi tersebut; 3) Untuk kesamaan mutu dalam memperolah materi, dikembangkan paket belajar terdistribusi yaitu materi belajar ditempatkan/disimpan di sebuah server yang tersambung ke internet sehingga dapat diambil oleh peserta ajar, baik memakai WebBrowser ataupun File Transport Protocol atau FTP (aplikasi pengiriman file).

\section{Pembelajaran Elektronik (E-Learning)}

E-learning merupakan pembelajaran jarak jauh yang menggunakan teknologi komputer atau biasanya disebut internet. Henderson dalam Horton (2003) menjelaskan e-learning merupakan pembelajaran berbasis web yang bisa diakses dari internet. Kumar (2002) mendefinisikan e-learning sebagai sembarang pembelajaran yang menggunakan rangkaian elektronik (Local Area Network (LAN), Wide Area Network (WAN), atau internet) untuk menyampaikan isi pembelajaran, interaksi atau bimbingan. (Kamarga, 2000) mendefinisikan e-learning sebagai kegiatan belajar yang disampaikan melalui perangkat elektronik komputer yang memperoleh bahan belajar yang sesuai dengan kebutuhannya.

E-learning sendiri merupakan salah satu bentuk dari konsep distance learning. Bentuk e-learning sendiri cukup luas, sebuah portal yang berisi informasi ilmu pengetahuan yang dapat dikatakan sebagai situs e-learning, jadi e-learning atau internet enabled learning menggabungkan metode pengajaran dan teknologi sebagai sarana dalam belajar. $E$ learning merupakan proses belajar secara efektif yang dihasilkan dengan cara menggabungkan penyampaian materi secara digital yang terdiri dari dukungan dan layanan dalam belajar.

Lebih detail lagi Rosenberg (2001) 
mengategorikan e-learning dalam tiga kriteria dasar yaitu: 1) E-learning bersifat jaringan, yang membuatnya mampu memperbaiki secara cepat, menyimpan atau memunculkan kembali, mendistribusikan, dan sharing pembelajaran serta informasi. Kriteria ini sangatlah penting dalam e-learning, sehingga Rosenberg menyebutnya sebagai persyaratan absolute; 2) E-learning dikirimkan kepada pengguna melalui teknologi komputer dengan menggunakan standar teknologi internet; 3) E-learning terfokus pada pandangan pembelajaran yang paling luas, solusi pembelajaran yang mengungguli paradigma tradisional dalam pembelajaran.

Pembelajaran elektronik atau $e$ learning telah dimulai pada tahun 1970-an berbagai istilah digunakan untuk mengemukakan pendapat/gagasan tentang pembelajaran elektronik, antara lain adalah: online learning, internet-enabled learning, virtual learning, atau web-based learning.

Berdasarkan berbagai pengertian tersebut, maka dapat disimpulkan bahwa $e$ Learning merupakan proses instruksi atau pembelajaran yang melibatkan penggunaan peralatan elektronik dalam menciptakan, membantu perkembangan, menyampaikan, menilai dan memudahkan suatu proses belajar mengajar di mana mahasiswa sebagai pusatnya serta dilakukan secara interaktif kapanpun dan di manapun.

Setidaknya terdapat tiga fungsi pembelajaran elektronik bagi kegiatan pembelajaran di dalam kelas (classroom instruction), yaitu sebagai suplemen yang sifatnya pilihan/opsional, pelengkap (komplemen), atau pengganti Siahaan (2002), yakni: 1) Suplemen (Tambahan). Dikatakan berfungsi sebagai suplemen (tambahan), apabila mahasiswa memunyai kebebasan memilih, apakah akan memanfaatkan materi pembelajaran elektronik atau tidak. Dalam hal ini, tidak ada kewajiban/keharusan bagi mahasiswa untuk mengakses materi pembelajaran elektronik. Sekalipun sifatnya opsional, mahasiswa yang memanfaatkannya tentu akan memiliki tambahan pengetahuan atau wawasan. 2) Komplemen (Pelengkap). Dikatakan berfungsi sebagai komplemen (pelengkap) apabila materi pembelajaran elektronik diprogramkan untuk melengkapi materi pembelajaran yang diterima mahasiswa di dalam kelas. Sebagai komplemen berarti materi pembelajaran elektronik diprogramkan untuk menjadi materi reinforcement (pengayaan) atau remedial bagi mahasiswa di dalam mengikuti kegiatan pembelajaran konvensional. Materi pembelajaran elektronik dikatakan sebagai enrichment, apabila kepada mahasiswa yang dapat dengan cepat menguasai/memahami materi pelajaran yang disampaikan dosen secara tatap muka (fast learners) diberikan kesempatan untuk mengakses materi pembelajaran elektronik yang memang secara khusus dikembangkan untuk mereka. Tujuannya agar semakin memantapkan tingkat penguasaan mahasiswa terhadap materi pelajaran yang disajikan dosen di dalam kelas. Dikatakan sebagai program remedial, apabila kepada mahasiswa yang mengalami kesulitan memahami materi pelajaran yang disajikan dosen secara tatap muka di kelas (slow learners) diberikan kesempatan untuk memanfaatkan materi pembelajaran elektronik yang memang secara khusus dirancang untuk mereka. Tujuannya agar mahasiswa semakin lebih mudah memahami materi pelajaran yang disajikan dosen di kelas; 3) Substitusi (Pengganti). Beberapa perguruan tinggi di negara-negara maju memberikan beberapa alternatif model kegiatan pembelajaran kepada para mahasiswanya. Tujuannya agar para mahasiswa dapat secara fleksibel mengelola kegiatan pembelajaran sesuai dengan waktu dan aktivitas lain sehari-hari mahasiswa.

E-learning mempermudah interaksi antara mahasiswa dengan bahan atau materi pelajaran. Demikian juga interaksi antara mahasiswa dengan dosen maupun antara sesama mahasiswa. Mahasiswa dapat saling berbagi informasi atau pendapat mengenai berbagai hal yang menyangkut pelajaran ataupun kebutuhan pengembangan diri mahasiswa. Dosen dapat menempatkan bahan-bahan belajar dan tugas-tugas yang harus dikerjakan oleh mahasiswa di tempat tertentu di dalam web untuk diakses oleh para mahasiswa. Sesuai dengan kebutuhan, dosen dapat pula memberikan kesempatan kepada 
mahasiswa untuk mengakses bahan belajar tertentu maupun soal-soal ujian yang hanya dapat diakses oleh mahasiswa sekali saja dan dalam rentangan waktu tertentu pula.

Secara lebih rinci, manfaat e-learning dapat dilihat dari 2 sudut, yaitu:

Dari sudut mahasiswa dan dosen: 1) Dari Sudut Mahasiswa: e-learning memungkinkan berkembangnya fleksibilitas belajar yang tinggi. Artinya, mahasiswa dapat mengakses bahan-bahan belajar setiap saat dan berulang-ulang. Mahasiswa juga dapat berkomunikasi dengan dosen setiap saat. Dengan kondisi yang demikian ini, mahasiswa dapat lebih memantapkan penguasaannya terhadap materi pembelajaran. Manakala fasilitas infrastruktur tidak hanya tersedia di daerah perkotaan tetapi telah menjangkau daerah kecamatan dan perdesaan, maka kegiatan e-learning akan memberikan manfaat (Brown, 2000) kepada mahasiswa yang di antaranya: a) Belajar di sekolahsekolah kecil di daerah-daerah miskin untuk mengikuti mata pelajaran tertentu yang tidak dapat diberikan oleh sekolahnya; b) Mengikuti program pendidikan keluarga di rumah (home schooling) untuk mempelajari materi pembelajaran yang tidak dapat diajarkan oleh para orangtuanya, seperti bahasa asing dan keterampilan di bidang komputer; c) Merasa phobia dengan sekolah, atau mahasiswa yang dirawat di rumah sakit maupun di rumah, yang putus sekolah tetapi berminat melanjutkan pendidikannya, yang dikeluarkan oleh sekolah, maupun mahasiswa yang berada di berbagai daerah atau bahkan yang berada di luar negeri; d) Tidak tertampung di sekolah konvensional untuk mendapatkan pendidikan.

2) Dari Sudut Dosen, e-learning banyak memberikan manfaat bagi dosen, terutama yang berkaitan dengan: a) Lebih mudah melakukan pemutakhiran bahan-bahan belajar yang menjadi tanggungjawabnya sesuai dengan tuntutan perkembangan keilmuan yang terjadi; b) Mengembangkan diri atau melakukan penelitian guna peningkatan wawasannya karena waktu luang yang dimiliki relatif lebih banyak; c) Mengontrol kegiatan belajar mahasiswa. Bahkan dosen juga dapat mengetahui kapan mahasiswanya belajar, topik apa yang dipelajari, berapa lama sesuatu topik dipelajari, serta berapa kali topik tertentu dipelajari ulang; d) Mengecek apakah mahasiswa telah mengerjakan soalsoal latihan setelah mempelajari topik tertentu; dan e) Memeriksa jawaban mahasiswa dan memberitahukan hasilnya kepada mahasiswa.

Manfaat pembelajaran elektronik menurut Wulf (1996) terdiri atas empat hal, yaitu:

Pertama, meningkatkan kadar interaksi pembelajaran antara mahasiswa dengan dosen atau instruktur (enhance interactivity). Apabila dirancang secara cermat, pembelajaran elektronik dapat meningkatkan kadar interaksi pembelajaran, baik antara mahasiswa dengan dosen, antara sesama mahasiswa, maupun antara mahasiswa dengan bahan belajar (enhance interactivity). Berbeda halnya dengan pembelajaran yang bersifat konvensional. Tidak semua mahasiswa dalam kegiatan pembelajaran konvensional dapat, berani, atau memunyai kesempatan untuk mengajukan pertanyaan ataupun menyampaikan pendapatnya di dalam diskusi. Mengapa? Karena pada pembelajaran yang bersifat konvensional, kesempatan yang ada atau yang disediakan dosen untuk berdiskusi atau bertanyajawab sangat terbatas. Biasanya kesempatan yang terbatas ini juga cenderung didominasi oleh beberapa mahasiswa yang cepat tanggap dan berani. Keadaan yang demikian ini tidak akan terjadi pada pembelajaran elektronik. Mahasiswa yang malu maupun yang raguragu atau kurang berani memunyai peluang yang luas untuk mengajukan pertanyaan maupun menyampaikan pernyataan/pendapat tanpa merasa diawasi atau mendapat tekanan dari teman sekelas.

Kedua, memungkinkan terjadinya interaksi pembelajaran dari mana dan kapan saja (time and place flexibility). Mengingat sumber belajar yang sudah dikemas secara elektronik dan tersedia untuk diakses oleh mahasiswa melalui internet, maka mahasiswa dapat melakukan interaksi dengan sumber belajar ini kapan saja dan dari mana saja. Demikian juga dengan tugas-tugas kegiatan pembelajaran, dapat diserahkan kepada dosen 
begitu selesai dikerjakan. Tidak perlu menunggu sampai ada janji untuk bertemu dengan dosen. Mahasiswa tidak terikat ketat dengan waktu dan tempat penyelenggaraan kegiatan pembelajaran sebagaimana halnya pada pendidikan konvensional.

Ketiga, menjangkau mahasiswa dalam cakupan yang luas (potential to reach a global audience). Dengan fleksibilitas waktu dan tempat, maka jumlah mahasiswa yang dapat dijangkau melalui kegiatan pembelajaran elektronik semakin lebih banyak atau meluas. Ruang dan tempat serta waktu tidak lagi menjadi hambatan. Siapa saja, di mana saja, dan kapan saja, seseorang dapat belajar. Interaksi dengan sumber belajar dilakukan melalui internet. Kesempatan belajar benar-benar terbuka lebar bagi siapa saja yang membutuhkan.

Keempat, mempermudah penyempurnaan dan penyimpanan materi pembelajaran (easy updating of content as well as archivable capabilities). Fasilitas yang tersedia dalam teknologi internet dan berbagai perangkat lunak yang terus berkembang turut membantu mempermudah pengembangan bahan belajar elektronik. Demikian juga dengan penyempurnaan atau pemutakhiran bahan belajar sesuai dengan tuntutan perkembangan materi keilmuannya dapat dilakukan secara periodik dan mudah. Di samping itu, penyempurnaan metode penyajian materi pembelajaran dapat pula dilakukan, baik yang didasarkan atas umpan balik dari mahasiswa maupun atas hasil penilaian dosen selaku penanggungjawab atau pembina materi pembelajaran itu sendiri. Pengetahuan dan keterampilan untuk pengembangan bahan belajar elektronik ini perlu dikuasai terlebih dahulu oleh dosen yang akan mengembangkan bahan belajar elektronik. Demikian juga dengan pengelolaan kegiatan pembelajarannya sendiri. Harus ada komitmen dari dosen yang akan memantau perkembangan kegiatan belajar mahasiswanya dan sekaligus secara teratur memotivasi mahasiswanya.

Metode pengajaran tradisional masih kurang efektif jika dibandingkan dengan metode pengajaran modern. Sistem $e$ learning diharapkan bukan sekedar menggantikan tetapi diharapkan pula untuk dapat menambahkan metode dan materi pengajaran tradisional seperti diskusi dalam kelas, buku, CD-ROM dan pelatihan komputer non internet. Indikator-indikator yang terdapat dalam sistem e-learning menurut Kumar (2002) adalah:

1. Materi Belajar dan Soal Evaluasi. Materi dapat disediakan dalam bentuk modul yang disertai dengan soal evaluasi, serta hasil evaluasi dapat ditampilkan. Hasil tersebut dapat dijadikan sebagai tolak ukur dan pelajar mendapatkan apa yang dibutuhkan;

2. Komunitas. Mahasiswa dapat mengembangkan komunitas online untuk memperoleh dukungan dan berbagi informasi yang saling menguntungkan;

3. Dosen Online. Dosen selalu online untuk memberikan arahan kepada mahasiswa, menjawab pertanyaan dan membantu dalam diskusi;

4. Kesempatan Bekerja Sama. Adanya perangkat lunak yang dapat mengatur pertemuan online sehingga belajar dapat dilakukan secara bersamaan atau real time tanpa kendala jarak;

5. Multimedia. Penggunaan teknologi audio dan video dalam penyampaian materi sehingga menarik minat dalam belajar.

Penyelenggaraan kegiatan pembelajaran elektronik, dosen merupakan faktor yang sangat menentukan dan keterampilannya memotivasi mahasiswa menjadi hal yang krusial. Karena itu, dosen haruslah bersikap transparan menyampaikan informasi tentang semua aspek kegiatan pembelajaran sehingga mahasiswa dapat belajar secara baik untuk mencapai hasil belajar yang baik. Informasi yang dimaksudkan di sini menyakup hal-hal di bawah ini:

1. Alokasi waktu untuk mempelajari materi pembelajaran dan penyelesaian tugas-tugas.

2. Keterampilan teknologis yang perlu dimiliki mahasiswa untuk memperlancar kegiatan pembelajarannya, dan 
3. Fasilitas dan peralatan yang dibutuhkan dalam kegiatan pembelajaran.

\section{Mutu Belajar}

Mutu berasal dari bahasa Latin yaitu qualis, menurut Hamalik (2012) hasil belajar itu dapat terlihat dari terjadinya perubahan dari persepsi dan perilaku, termasuk juga perbaikan perilaku. Dimyati dan Mudjiono (2006) menyatakan bahwa kegiatan guru secara terprogram dan terencana dalam desain instruksional, untuk membuat peserta didik belajar secara aktif, yang menekankan pada penyediaan sumber belajar. Gage dan Berliner dalam Dimyati dan Mudjiono (2006) menyatakan bahwa belajar dapat didefinisikan sebagai suatu proses yang membuat seseorang mengalami perubahan tingkah laku sebagai hasil dari pengalaman yang diperolehnya. Oleh karena itu penggunaan istilah mutu pembelajaran secara sederhana dapat diartikan dengan kualitas ataupun keunggulan proses pembelajaran yang dilaksanakan oleh dosen, ditandai dengan kualitas lulusan atau output institusi perguruan tinggi.

Merupakan suatu hal yang mustahil, pendidikan atau perguruan tinggi menghasilkan lulusan yang bermutu, jika tidak melalui proses pendidikan yang bermutu. Merupakan sesuatu yang mustahil pula, terjadi proses pendidikan yang bermutu jika tidak didukung oleh faktor-faktor penunjang proses pendidikan yang bermutu. Proses pendidikan yang bermutu harus didukung oleh administrator, dosen, konselor, tata usaha yang bermutu dan profesional. Ini artinya ketika membahas tentang mutu pendidikan maka seluruh unsur yang terkait dengan usaha mencapai mutu pendidikan itu juga harus dibahas secara tuntas, sebab mutu pendidikan adalah kondisi output, ataupun hasil akumulasi dari sebuah proses kependidikan pada sebuah lembaga pendidikan.

Mutu pembelajaran pada hakikat adalah target yang harus dicapai dosen dalam melaksanakan proses pembelajaran. Mutu belajar hanya akan dicapai dosen dengan memberikan pelayanan yang baik dan memuaskan terhadap mahasiswa, karena dengan pelayanan yang baik dan dapat memuaskan mahasiswa, maka proses pembelajaran dapat mencapai tujuan yang telah ditetapkan.

Surya dalam Rusman menyatakan bahwa belajar dapat diartikan sebagai suatu proses dilakukan oleh individu untuk memeroleh perubahan perilaku baru secara keseluruhan, sebagai hasil dari pengalaman itu sendiri dalam berinteraksi dengan lingkungannya. Peningkatan etos kerja akan merupakan palengkap dari usaha untuk meningkatkan mutu produk kerja dan semangat profesionalisme. Keberhasilan atau kegagalan dosen dalam meningkatkan mutu hasil pendidikan, profesionalisme, dan etos kerja akan dapat dirasakan oleh masyarakat melalui profil para lulusannya.

Whitaker dalam Rusman (2012) belajar adalah proses di mana tingkah laku ditimbulkan atau diubah melalui latihan dan pengalaman kegiatan belajar dan mengajar merupakan kegiatan yang paling pokok. Hal tersebut berarti berhasil tidaknya pencapaian tujuan pendidikan banyak bergantung kepada bagaimana proses belajar mengajar dirancang dan dijalankan secara profesional. Uno (2012) menyatakan bahwa belajar adalah suatu proses usaha yang dilakukan individu untuk memeroleh suatu perubahan tingkah laku secara keseluruhan sebagai hasil pengalaman individu itu sendiri dalam interaksi dengan lingkungannya. Prinsip belajar perlu sejalan dengan empat pilar pendidikan universal seperti dirumuskan oleh UNESCO, yaitu belajar untuk mengetahui (learning to know); belajar untuk melakukan (learning to do); belajar menjadi (learning to be); dan belajar untuk hidup bersama (learning to live together).

Dosen harus pandai memilih materi pembelajaran yang akan disampaikan serta bagaimana proses belajar tersebut harus dikelola dan dilaksanakan di dalam kelas. Proses pembelajaran yang bermutu merupakan kemampuan dosen menggunakan seluruh komponen yang dapat mendukung terwujudnya proses pembelajaran yang bermutu. Danim (2006) menyatakan bahwa 
mutu proses pembelajaran mengandung makna bahwa kemampuan sumber daya lembaga pendidikan menransformasikan multi jenis masukan dan situasi mencapai derajat nilai tambah tertentu bagi peserta didik. Sehingga dapat dikatakan bahwa proses pembelajaran yang dilaksanakan dengan bervariasi yang lebih baik dalam meningkatkan mutu pendidikan.

Menurut Bloom, dkk. dalam Dimyati dan Mudjiono (2006) mutu belajar dapat diukur dengan enam jenis indikator sebagai berikut: 1) Pengetahuan (Knowledge) mencapai kemampuan ingatan tentang hal yang telah dipelajari dan tersimpan dalam ingatan; 2) Pemahaman (Comprehension). Mencakup kemampuan menangkap arti dan makna tentang hal yang telah di pelajari. 3) Penerapan (Aplication). Mencakup kemampuan menerapkan metode dan kaidah untuk menghadapi masalah yang nyata dan baru. 4) Analisis (Analysis). Mencakup kemampuan merinci suatu kesatuan ke dalam bagian-bagian sehingga struktur keseluruhan dapat dipahami dengan baik. 5) Sintesis (Synthesis). Mencakup kemampuan membentuk suatu pola baru. 6) Evaluasi (Evaluation). Mencakup kemampuan membentuk pendapat tentang beberapa hal berdasarkan kriteria tertentu.

\section{Hipotesis}

Hipotesis dalam penelitian ini dirumuskan sebagai berikut: pembelajaran elektronik (elearning) berpengaruh positif dan signifikan terhadap mutu belajar mahasiswa FKIP UNINUS Bandung.

\section{METODE PENELITIAN}

Penelitian ini menggunakan metode deskriptif verifikatif. Malhotra (2004) menyatakan bahwa penelitian deskriptif adalah suatu jenis riset konklusif yang memunyai tujuan utama menguraikan sesuatu, sedangkan penelitian verifikatif menurut Mashuri dan Zainudin (2009) adalah memeriksa benar tidaknya apabila dijelaskan untuk menguji suatu cara dengan atau tanpa perbaikan yang telah dilaksanakan di tempat lain dengan mengatasi masalah yang serupa dengan kehidupan.

Penelitian ini dilaksanakan dalam kurun waktu tertentu yang keberlakuannya terikat dalam metode dan jenis penelitian yang ditetapkan. Dengan pemahaman tersebut, maka penelitian ini dikembangkan dalam model pengembangan cross-sectional.

Operasionalisasi variabel penelitian yang disajikan dalam Tabel 1 berikut ini.

\section{Tabel 1}

\section{Operasionalisasi Variabel Penelitian}

\begin{tabular}{|c|c|c|c|}
\hline Variabel & Dimensi & Indikator & Skala \\
\hline \multirow[t]{3}{*}{$\begin{array}{l}\text { E-Learning } \\
\text { (X) }\end{array}$} & $\begin{array}{l}\text { Materi Belajar } \\
\text { dan Evaluasi }\end{array}$ & $\begin{array}{l}\text { - Materi belajar mahasiswa tersedia secara online dan dapat } \\
\text { diunduh } \\
\text { - Soal-soal latihan pendalaman materi perkuliahan tersedia } \\
\text { secara online dan dapat diunduh } \\
\text { - Evaluasi belajar mahasiswa tersedia secara online dan dapat } \\
\text { diunduh }\end{array}$ & Ordinal \\
\hline & Komunitas & $\begin{array}{l}\text { - Mahasiswa mengembangkan komunitas online antar sesama } \\
\text { tema } \\
\text { - Mahasiswa berbagai informasi perkuliahan dalam komunitas } \\
\text { yang dibentuk } \\
\text { - Mahasiswa berbagi ilmu yang diperoleh dari mata kuliah }\end{array}$ & Ordinal \\
\hline & Dosen Online & $\begin{array}{l}\text { - Mahasiswa mamperoleh bimbingan dari dosen secara online } \\
\text { - Dosen terlibat aktif dalam komunitas yang dibentuk oleh } \\
\text { mahasiswa } \\
\text { - Dosen mampu memberikan tambahan ilmu secara online, } \\
\text { dimana dosen tidak mampu memberikannya di dalam kelas. }\end{array}$ & Ordinal \\
\hline
\end{tabular}




\begin{tabular}{|c|c|c|c|}
\hline Variabel & Dimensi & Indikator & Skala \\
\hline & $\begin{array}{l}\text { Kesempatan } \\
\text { Bekerja Sama }\end{array}$ & $\begin{array}{l}\text { - Terdapat dukungan software messenger yang memudahkan } \\
\text { dosen dan mahasiswa melakukan interaksi real time } \\
\text { - Terdapat dukungan software messenger yang memudahkan } \\
\text { antarmahasiswa untuk melakukan interaksi real time } \\
\text { - Terdapat dukungan software messenger yang memudahkan } \\
\text { antarmahasiswa untuk melakukan kerjasama dalam } \\
\text { menyelesaikan masalah perkuliahan. }\end{array}$ & Ordinal \\
\hline & Multimedia & $\begin{array}{l}\text { - Dosen menyediakan media pembelajaran berbentuk video } \\
\text { - Dosen menyediakan media pembelajaran berbentuk audio } \\
\text { - Dosen menyediakan media pembelajaran berbentuk simulasi } \\
\text { online }\end{array}$ & Ordinal \\
\hline \multirow{6}{*}{$\begin{array}{l}\text { Mutu Belajar } \\
\text { (Y) }\end{array}$} & Pengetahuan & $\begin{array}{l}\text { - Mahasiswa mendapatkan konsep-konsep pengetahuan baru } \\
\text { - Mahasiswa mendapatkan pengalaman baru } \\
\text { - Mahasiswa mendapatkan pendalaman materi yang berguna } \\
\text { bagi penambahan pengetahuan }\end{array}$ & Ordinal \\
\hline & Pemahaman & $\begin{array}{l}\text { - Mahasiswa memahami defenisi-defenisi penting dari mata } \\
\text { kuliah } \\
\text { - Mahasiswa memahami kerangka umum mata kuliah } \\
\text { - Mahasiswa memahami intisari mata kuliah }\end{array}$ & Ordinal \\
\hline & Penerapan & $\begin{array}{l}\text { - Mahasiswa memadukan konsep yang satu dengan konsep } \\
\text { yang lainnya sehingga memeroleh generalisasi } \\
\text { - Mahasiswa menerapkan teori dari mata kuliah terhadap } \\
\text { masalah kehidupan } \\
\text { - Mahasiswa mengembangkan teori yang diperoleh dengan } \\
\text { kejadian dalam kehidupan }\end{array}$ & Ordinal \\
\hline & Analisis & $\begin{array}{l}\text { - Mahasiswa menganalisis mata kuliah yang dipelajari } \\
\text { - Mahasiswa menganalisis tema inti dalam mata kuliah yang } \\
\text { dipelajari } \\
\text { - Mahasiswa membandingkan materi yang dipelajari dengan } \\
\text { sumber-sumber rujukan lainnya }\end{array}$ & Ordinal \\
\hline & Sintesis & $\begin{array}{l}\text { - Mahasiswa memeroleh inspirasi } \\
\text { - Mahasiswa mengembangkan pola pikir baru } \\
\text { - Mahasiswa mengembangkan metode belajar baru }\end{array}$ & Ordinal \\
\hline & Evaluasi & $\begin{array}{l}\text { - Mahasiswa mengevaluasi tingkat pengetahuan yang } \\
\text { dimilikinya } \\
\text { - Mahasiswa mengevaluasi tingkat ketercapaian materi } \\
\text { pembelajaran } \\
\text { - Mahasiswa mengevaluasi tingkat keberhasilannya dalam } \\
\text { mata kuliah }\end{array}$ & Ordinal \\
\hline
\end{tabular}

$$
\mathrm{n}=\frac{\mathrm{N}}{1+\mathrm{Ne}^{2}}
$$

Populasi penelitian ini adalah mahasiswa FKIP UNINUS Bandung Angkatan Tahun 2012-2013 yang berjumlah 280 Mahasiswa (Data Bagian Akademik FKIP UNINUS, 2013). Berdasarkan jumlah populasi tersebut, selanjutnya dihitung ukuran sampel minimal dengan menggunakan rumus Slovin (Umar, 2008) sebagai berikut: Keterangan:

$$
\mathrm{n}: \text { ukuran sampel }
$$

$$
\begin{aligned}
& \mathrm{N} \text { : ukuran populasi } \\
& \mathrm{e}: \text { taraf kesalahan }
\end{aligned}
$$

Berdasarkan hasil perhitungan sampel, diperoleh unit analisis sampel sebesar 100,2 sampel, karena sampel dalam penelitian ini orang yang tidak dapat dihitung secara desimal, maka 100,2 sampel dibulatkan menjadi 100 sampel.

Instrumen utama yang digunakan dalam penelitian ini adalah angket. Menurut Sugiyono (2010), angket adalah teknik 
pengumpulan data yang dilakukan dengan cara memberi seperangkat pertanyaan atau pernyataan tertulis kepada responden untuk dijawabnya. Angket merupakan teknik pengumpulan data yang efisien jika peneliti tahu dengan pasti variabel yang akan diukur dan tahu apa yang tidak bisa diharapkan dari responden. Angket sebagai teknik pengumpulan data sangat cocok untuk mengumpulkan data dalam jumlah besar.

Selanjutnya angket disebarkan kepada mahasiswa sesuai dengan unit analisis yang telah ada dengan teknik sampel menggunakan simple random sampling.

Penelitian ini menggunakan dua jenis analisis, yaitu: (1) Analisis deskriptif, khususnya bagi variabel yang bersifat kualitatif dan (2) Analisis verifikatif berupa pengujian hipotesis dengan menggunakan uji statistik bagi data yang bersifat kuantitatif. Analisis deskriptif digunakan untuk melihat faktor penyebab sedangkan analisis verifikatif menitikberatkan pada pengungkapan perilaku variabel yang diteliti. Penelitian ini terdiri dari jaringan variabel yang memunyai keterkaitan satu sama lainnya. Untuk dapat menganalisis secara lebih mendalam, maka perlu dideteksi hubungan antara variabel yang diteliti.

Sebelum data dianalisis lebih mendalam, terlebih dahulu digunakan uji asumsi normalitas dan uji homogenitas. Uji asumsi normalitas digunakan untuk mengetahui apakah dalam sebuah model regresi, nilai residu dari model regresi tersebut memunyai distribusi yang normal. Jika distribusi dari nilai-nilai residual tersebut tidak dapat dianggap berdistribusi normal, maka dikatakan ada masalah terhadap asumsi normalitas (Santoso, 2012). Sedangkan uji homogenitas dimaksudkan untuk memperlihatkan bahwa dua atau lebih kelompok data sampel berasal dari populasi yang memiliki variansi yang sama.

Teknik analisis data dan pengujian hipotesis yang digunakan dalam penelitian ini ialah menggunakan regresi linear dengan bantuan program komputer SPSS versi 21.00. Sugiyono (2010) menyatakan bahwa analisis regresi linier digunakan oleh peneliti apabila peneliti bermaksud meramalkan bagaimana keadaan (naik turunnya) variabel dependen (kriterium), apabila variabel independen sebagai faktor prediktor dimanipulasi (dinaikturunkan nilainya).

\section{HASIL PENELITIAN DAN PEMBAHASAN}

\section{E-Learning di FKIP UNINUS}

Berdasarkan hasil pengolahan data diperoleh rekapitulasi tanggapan mahasiswa terhadap e-learning, diketahui bahwa $e$ learning di FKIP UNINUS Bandung berada dalam kategori yang tinggi. Indikator materi belajar dan soal evaluasi merupakan indikator yang paling tinggi berkontribusi terhadap $e$ learning, sedangkan kesempatan bekerjasama merupakan indikator yang memiliki kontribusi paling rendah terhadap e-learning.

\section{Mutu Belajar Mahasiswa FKIP UNINUS}

Berdasarkan hasil pengolahan data, diketahui bahwa mutu belajar mahasiswa FKIP UNINUS Bandung berada dalam kategori yang sedang. Indikator pengetahuan merupakan indikator yang paling tinggi berkontribusi terhadap mutu belajar, sedangkan analisis merupakan indikator yang memiliki kontribusi paling rendah terhadap mutu belajar.

\section{Pengaruh E-Learning terhadap Mutu Belajar Mahasiswa FKIP UNINUS}

Banyak sekali teknik pengujian normalitas suatu distribusi data yang telah dikembangkan oleh para ahli, salah satunya dengan menggunakan teknik Kolmogorov Smirnov (Sujianto, 2007). Hasil pengujian normalitas data dengan menggunakan Kolmogorov Smirnov disajikan dalam Tabel 2 berikut: 


\section{Tabel 2}

Hasil Uji Normalitas Data

One-Sample Kolmogorov-Smirnov Test

\begin{tabular}{|c|c|c|c|}
\hline & & E-Learning & $\begin{array}{l}\text { Mutu } \\
\text { Belajar }\end{array}$ \\
\hline $\mathrm{N}$ & & 100 & 100 \\
\hline \multirow{2}{*}{ Normal Parameters ${ }^{a, b}$} & Mean & 70.48 & 55.23 \\
\hline & Std. Deviation & 7.75132 & 6.26328 \\
\hline \multirow[t]{3}{*}{ Most Extreme Differences } & Absolute & 0.075 & 0.059 \\
\hline & Positive & 0.06 & 0.051 \\
\hline & Negative & -0.062 & -.059 \\
\hline Kolmogorov-Smirnov Z & & 0.878 & 0.693 \\
\hline Asymp. Sig. (2-tailed) & & 0.882 & .667 \\
\hline
\end{tabular}

a. Test distribution is Normal.

b. Calculated from data.

Sumber: Hasil Pengolahan Data

Berdasaran hasil uji normalitas, diketahui bahwa data dalam variabel $e$ learning dan mutu belajar terdistribusi secara normal, sehingga layak untuk digunakan sebagai bahan dalam tahap pengolahan data berikutnya. Setelah dilakukan uji normalitas data, selanjutnya disajikan uji homogenitas data. Uji homogenitas dimaksudkan untuk memperlihatkan bahwa dua atau lebih kelompok data sampel berasal dari populasi yang memiliki variansi yang sama.

Tabel 3

Hasil Uji Homogenitas Data Levene's Test of Equality of Error Variances ${ }^{a}$

\begin{tabular}{cccc}
\hline F & df1 & df2 & Sig. \\
\hline 1.432 & 24 & 88 & 0.078 \\
\hline
\end{tabular}

Tests the null hypothesis that the error variance of the dependent variable is equal across groups.

a. Design: Intercept + E-Learning

Sumber: Hasil Pengolahan Data

Pada kolom Sig. menunjukkan nilai sign. di atas 0,05 , yaitu 0,078 . Dengan demikian data penelitian sudah bersifat homogen. Setelah diketahui data bersifat normal dan homogen, selanjutnya dilakukan analisis regresi.

Analisis regresi digunakan untuk mengetahui ada tidaknya pengaruh e-learning terhadap mutu belajar mahasiswa FKIP UNINUS Bandung. Teknik analisis yang digunakan dalam penelitian ini adalah analisis regresi linear dengan menggunakan aplikasi sotware SPSS 21.00. Berdasarkan hasil pengujian, diperoleh hasil seperti disajikan dalam Tabel 4 sebagai berikut 
Tabel 4

Uji Signifikansi Pengaruh E-Learning

terhadap Mutu Belajar

ANOVA $^{\text {b }}$

\begin{tabular}{crcrrr}
\hline Model & Sum of Squares & Df & Mean Square & \multicolumn{1}{c}{ F } & \multicolumn{1}{c}{ Sig. } \\
\hline 1 Regression & 3142.054 & 1 & 3122.094 & 324.075 & $.000^{\mathrm{a}}$ \\
Residual & 594.916 & 98 & 5.081 & & \\
Total & 3827.61 & 99 & & & \\
\hline
\end{tabular}

a. Predictors: (Constant), E-Learning

b. Dependent Variable: Mutu Belajar

Sumber: Hasil Pengolahan Data

Berdasarkan Tabel 4, dapat diketahui tingkat signifikansi sebesar 0,000. Karena probabilitas 0,000 jauh lebih kecil dari 0,05, maka dapat disimpulkan bahwa e-learning berpengaruh terhadap mutu belajar. Berdasarkan hasil tersebut, selanjutnya dihitung persamaan regresi. Persamaan regresi digunakan untuk melakukan prediksi seberapa tinggi nilai variabel mutu belajar bila variabel e-learning dimanipulasi. Hasil perhitungan dengan menggunakan software SPSS 21.00. disajikan dalam Tabel 5.

Tabel 5

Koefisien Regresi Pengaruh E-Learning terhadap Mutu Belajar Coefficients $^{\text {a }}$

\begin{tabular}{|c|c|c|c|c|c|}
\hline \multirow[t]{2}{*}{ Model } & \multicolumn{2}{|c|}{$\begin{array}{l}\text { Unstandardized } \\
\text { Coefficients }\end{array}$} & \multirow{2}{*}{$\begin{array}{c}\text { Standardized } \\
\text { Coefficients } \\
\text { Beta }\end{array}$} & \multirow[t]{2}{*}{$\mathrm{t}$} & \multirow[t]{2}{*}{ Sig. } \\
\hline & $\mathrm{B}$ & Std. Error & & & \\
\hline 1 (Constant) & 5.664 & 2.054 & & 4.578 & 0.001 \\
\hline E-Learning & 0.812 & 0.04 & .970 & 18.024 & 0 \\
\hline
\end{tabular}

a. Dependent Variable: Mutu Belajar Sumber: Hasil Pengolahan Data

Berdasarkan tabel 5, dapat dijelaskan bahwa konstanta sebesar 5,664 menyatakan jika tidak ada e-learning, maka mutu belajar sebesar 5,664. Sedangkan koefisien regresi sebesar 0,812 menyatakan bahwa setiap penambahan satu kali untuk e-learning maka mutu belajar akan meningkat sebesar 0,812 . Sebaliknya, jika e-learning turun satu kali, maka mutu belajar juga diprediksi akan mengalami penurunan sebesar 0,812 .

Persamaan regresi linier sederhana antara e-learning dan mutu belajar adalah: Mutu Belajar $=5,664+0,812$ E-Learning $Y=5,664+0,812 X$

Pengujian signifikansi konstanta dapat dilakukan dengan membandingkan nilai $t$ tabel dengan harga $\mathrm{t}$ hitung, untuk taraf kesalahan $5 \%$ uji satu pihak dengan $\mathrm{dk}=\mathrm{n}-1$, maka diperoleh t tabel sebesar 1,66. Karena nilai $\mathrm{t}$ hitung lebih besar dari pada $\mathrm{t}$ tabel $(18,024>1,66)$, maka hipotesis diterima. Hal ini berarti terdapat pengaruh positif dan signifikan dari e-learning terhadap mutu belajar mahasiswa FKIP UNINUS Bandung.

Besarnya pengaruh e-learning terhadap mutu belajar dapat diketahui melalui hasil uji koefisien determinasi. Koefisien determinasi diketahui dengan cara mengkuadratkan koefisien korelasi yang telah ditemukan, dan selanjutnya dikalikan dengan $100 \%$ (Sugiyono, 2010). 


\section{Tabel 6}

\section{Koefisien Determinasi Pengaruh E-Learning terhadap Mutu Belajar Model Summary}

\begin{tabular}{rrrrr} 
Model & \multicolumn{1}{c}{ R } & R Square & \multicolumn{1}{c}{$\begin{array}{c}\text { Adjusted R } \\
\text { Square }\end{array}$} & \multicolumn{2}{c}{$\begin{array}{c}\text { Std. Error of the } \\
\text { Estimate }\end{array}$} \\
\hline 1 & $.886^{\mathrm{a}}$ & .785 & 0.786 & 3.55094 \\
\hline
\end{tabular}

a. Predictors: (Constant), E-Learning

Sumber: Hasil Pengolahan Data

Berdasarkan tabel 6 diketahui bahwa nilai R (korelasi) sebesar 0,785. Kontribusi $e$ learning sebagai variabel bebas atau variabel yang memengaruhi terhadap mutu belajar mahasiswa sebesar 0,785 atau $78,5 \%$, dan sisanya sebesar $21,5 \%$ dipengaruhi oleh faktor lain yang tidak diteliti dalam penelitian ini, misalnya ketearmpilan dosen. Kontribusi tersebut menunjukkan bahwa pengaruh $e$ learning terhadap mutu belajar berada pada klasifikasi yang kuat, karena nilai tersebut berada pada kisaran $0,600-0,799$.

Hasil tersebut sesuai dengan hasil penelitian yang telah dilakukan oleh Tafiardi (2005) yang menyatakan bahwa sejalan dengan perkembangan ilmu dan teknologi terutama teknologi informasi, pemanfaatan internet dalam bidang pendidikan terus berkembang. Pemanfaatan internet ini tidak hanya untuk pendidikan jarak jauh, akan tetapi juga dikembangkan dalam sistem pendidikan konvensional. E-learning adalah suatu model pembelajaran yang dibuat dalam format digital melalui perangkat elektronik. Tujuan digunakannya e-learning dalam sistem pembelajaran adalah untuk memperluas akses pendidikan kemasyarakat luas, serta dalam rangka meningkatkan mutu belajar.

Temuan tersebut juga didukung oleh Purbo (2001) yang menyatakan bahwa paling tidak ada tiga hal dampak positif penggunaan internet dalam pendidikan yaitu: a) Peserta didik dapat dengan mudah mengambil mata kuliah di mana pun di seluruh dunia tanpa batas institusi atau batas negara; b) Peserta didik dapat dengan mudah berguru pada para ahli di bidang yang diminatinya; c) Kuliah/belajar dapat dengan mudah diambil di berbagai penjuru dunia tanpa bergantung pada universitas/sekolah tempat si mahasiswa belajar. Di samping itu kini hadir perpustakan internet yang lebih dinamis dan bisa digunakan di seluruh jagat raya.

\section{PENUTUP}

\section{Simpulan}

E-learning di FKIP UNINUS Bandung berada dalam kategori tinggi. Indikator materi belajar dan soal evaluasi merupakan indikator yang paling tinggi berkontribusi terhadap $e$ learning, sedangkan kesempatan bekerjasama merupakan indikator yang memiliki kontribusi paling rendah terhadap e-learning.

Mutu belajar mahasiswa FKIP UNINUS Bandung berada dalam kategori sedang. Indikator pengetahuan merupakan indikator yang paling tinggi berkontribusi terhadap mutu belajar, sedangkan analisis merupakan indikator yang memiliki kontribusi paling rendah terhadap mutu belajar.

E-learning berpengaruh positif dan signifikan terhadap mutu belajar mahasiswa FKIP UNINUS Bandung. Pengaruh tersebut berada dalam kategori yang kuat. Semakin intensif e-learning dimanfaatkan, maka mutu belajar mahasiswa FKIP UNINUS akan semakin meningkat pula.

\section{Saran}

Kesempatan bekerjasama sebagai salah satu indikator e-learning di FKIP Bandung perlu ditingkatkan melalui peningkatan sosialisasi dan komunikasi bahwa e-learning merupakan sarana dan media pembelajaran yang efektif dalam mengembangkankan sikap dan perilaku kerjasama, oleh karena itu, perlu diwajibkan kepada mahasiswa untuk melakukan kerjasama di forum-forum yang ada dan berkembangan di e-learning FKIP 
UNINUS Bandung.

Kemampuan mahasiswa dalam melaksanakan analisis perlu ditingkatkan dengan cara memberikan evaluasi berupa studi kasus, sehingga mahasiswa mampu mengasah keterampilan analisisnya.

E-Learning beserta indikatorindikatornya secara keseluruhan perlu untuk dioptimalkan, karena terbukti berpengaruh secara positif dan signifikan terhadap mutu belajar mahasiswa FKIP UNINUS Bandung.

\section{DAFTAR PUSTAKA}

\section{Buku:}

Brown, D. H. (2000). Principles of Language Learning and Teaching. San Fransisco: Longman.

Danim, Sudarwan. (2006). Visi Baru Manajemen Sekolah: Dari Unit Birokrasi ke Lembaga Akademik. Jakarta: Bumi Akasara.

Dimyati dan Mudjiono. (2006). Belajar dan Pembelajaran. Jakarta: Rineka Cipta.

Hamalik, Oemar. (2012). Kurikulum dan Pembelajaran. Jakarta: Bumi Aksara.

Horton, William dan Horton, Katherine. (2003). E-Learning Tools and Technologies: A Consumer Guide for Trainers, Teachers, Educators, and Instructional Designers. USA: Wiley Publishing, Inc.

Kumar, Jaya C. (2002). Aplikasi E-Learning dalam Pengajaran dan Pembelajaran di Sekolah Malaysia. Jakarta.

K. Wulf. (1996). Implementing eLearning: Getting the Most from Your Elearning Investment. The ASTD International Conference.

Kamarga. (2000). Sistem E-Learning. Jakarta: Salemba Empat.

Karwati, Euis. (2013). Peningkatan Mutu Belajar Mahasiswa Uninus melalui Pengembangan Sistem Informasi Pembelajaran. Bandung: Laporan Penelitian LPPM UNINUS.

Malhotra, N. K. (2004). Riset: Pendekatan Terapan. Jakarta: PT. Indeks Kelompok
Gramedia.

Mashuri dan M. Zainudin. (2009). Metodologi Penelitian: Pendekatan Praktis dan Aplikatif. Bandung: Refika Aditama.

Rosenberg. (2001). Pemanfaatan Multimedia dalam Pendidikan. Newyork: Addison Wesley Longman.

Rusman. (2012).

Model-model Pembelajaran. Jakarta: PT Raja Grafindo Persada.

Santoso, Singgih. (2012). Analisis SPSS pada Statistik Parametrik. Jakarta: PT. Elex Media Komput Indo.

Siahaan, S.M. (2002). Analisis Motif Mengajar Guru dalam Membangun Pemahaman Instrumental dan Pemahaman Relasional Siswa dengan Menggunakan Skema Pemecahan Masalah Berdasarkan Model Argumentasi Toulmin. Bandung: SPs. UPI.

Sugiyono. (2010). Metode Penelitian. Bandung: CV. Alfabeta.

Sujianto, Agus Eko. (2007). Aplikasi Statistik dengan SPSS untuk Pemula. Jakarta: Prestasi Pustaka.

Umar, Husein. (2008). Riset Sumber Daya Manusia dalam Organisasi. Jakarta: Gramedia Pustaka Utama.

Uno, Hamzah B. (2012). Profesi Kependidikan (Problematika, Solusi, dan Revormasi Pendidikan di Indonesia. Jakarta: Bumi Aksara.

\section{Jurnal:}

Tafiardi. (2005). Meningkatkan Mutu Pendidikan Melalui E-Learning. Jurnal Pendidikan Penabur No.04 Th.IV Juli 2005. hal. 23-43.

\section{Internet:}

Purbo, Onno W. (2001). Masyarakat Pengguna Internet di Indonesia. Tersedia dalam http://www.geocities.com/inrecent/proje ct.html. Diakses tanggal 5 Oktober 2013. 